\title{
COMPARING THE PERFORMANCE OF SEEDLING GROWTH OF ACACIA SENEGAL UNDER SHADE AND DIRECT SUNLIGHT
}

\author{
Yahia I.M. Abutaba and Zeinab M. Hammad \\ University of Kordofan, Sudan \\ https://doi.org/10.35410/IJAEB.2020.5534
}

\begin{abstract}
This research is intended to contribute to knowledge concerning tree establishment. The study was conducted in the season 2016-2017 to assess the effect of sowing date and shade on seedling performance of Acacia senegal. The experiment was carried out at the Nursery of the Institute of Gum Arabic Research and Desertification Studies, University of Kordofan, El Obeid, Sudan. The experimental design used was the complete block design method where three different sowing dates replicated four times, this was conducted under direct sun light and under shade, and the experimental unit consists of 80 seedlings. Excel was used for data analysis. Study results showed significant the length and number of leaves were very high significant affected by the sowing date, shade and under sun $(\mathrm{p}=0.0001)$. Diameter was no significantly by the sowing date, shade and under sun. However October 10th sowing had significantly bigger root collar diameter compared to all sowing date. The Seedlings under shade recorded the longest seedling length $(25.3 \mathrm{~cm})$ and number of leaves showed high significant under sun (18.2 leaves).

There is a hardening and rapid establishment of seedlings that were planted outside the shade and this appears by increasing the number of leaves for the seedlings, and these are advantages of plantation establishment for their dependence on photosynthesis.
\end{abstract}

Keywords: seedlings, under shade, sunlight, Acacia senegal.

\section{INTRODUCTION}

The Gum Arabic tree (Acacia senegal (L.) Willd. or senegalia Senegal (L.) Britton) is a legume tree from the dry tropics and subtropics. It is valued for the production of Gum Arabic, the only acacia gum evaluated as a safe food additive. The Gum Arabic tree is a low branching, small, and spiny tree, which grows up to 7-15 $\mathrm{m}$ in height with a girth of about $1.3 \mathrm{~m}$ (Kew Gardens, 2016).

The Gun Arabic tree is native to Western Sudan, Nigeria and the Arabian Peninsula. The Gum Arabic belt in Sudan extends across 52000 square kilometers, covering one fifth of the area of the country. The main Gum Arabic trees in Sudan are Hashab (Acacia Senegal) and Talih (Acacia seyal). These trees are grown under shifting cultivation system (bush fallow system). Gum Arabic natural resources, the main gum-producing areas of Northern Kordofan and 
Northern Darfur areas suffered substantial ecological and socio-economic deterioration (Taha, 1999).

In Sudan, the gum from Acacia senegal and Acacia seyal are separated in both national statistics and trade (FAO, 1995). Unlike Acacia senegal, Acacia seyal in Sudan has not been cultivated for gum production (Fadl and Gebauer, 2004).

The species grows naturally in the central clay plains of the Sudan (Mustafa, 1997) and extensively managed for firewood and charcoal production (Elsiddig, 2003).

Acacia senegal is a multipurpose African tree (sub family Mimosoideae, family Leguminosae), highly valued for centuries for gum Arabic production. Today, Acacia senegal is grown primarily for gum, although its plays secondary roles in agricultural systems, restoring soil fertility and providing fuel and fodder. It is one of the few trees that can be grown economically in the sub desert zone relying on rainfall alone for its soil moisture (Okatahi, 1999). This paper reviews some of the local and temporal differences of the Hashab (Acacia senegal) tree in the post-germination stage of the nursery.

\section{MATERIAL AND METHODS}

The experiment was conducted in the nursery of the Institute of Gum Arabic research and desertification Studies - University of Kordofan, Sudan, during the period October and November 2016.

Experiment site is $13^{\circ}: 11 " \mathrm{~N}$ and $30^{\circ}: 12$ " E, $650 \mathrm{~m}$ above sea level, with mean annual rainfall of $308 \mathrm{~mm}$ and average temperature $21^{\circ}$ and $38^{\circ}$.

A randomized complete block design was used. Seeds were collected from high yielding trees. After holding germination test, 80 seedlings where planted under shade and 80 were planted under direct sun light, each treatment was replicated four times. Four sowing dates were considered 10th and 25th of October, and 10th and 25th of November. Flood irrigation as well as other necessary operations like weeding and singling was applied. A random sample of $30 \%$ was used for growth performance measurement and destructive samples were used to determine the biomass.

\section{Data analysis}

Analysis of Variance (ANOVA) was applied using SAS statistical software version 6.12 (SAS Institute Inc., 1996). The Duncan New Multiple Range Test was used to separate the means and to determine levels of significance the seedlings planted under shade and sun; and sowing in period time.

\section{RESULTS}

Length and number of leaves were very high significant affected by the sowing date, shade and under sun $(\mathrm{p}=0.0001)(\mathrm{R} 2=0.0141,0.025)$. Diameter was no significantly by the sowing date, shade and under sun. 
October10th recorded the longest seedling shoot length $(24.6 \mathrm{~cm})$ followed by october25th as $(18.6 \mathrm{~cm})$ and November10th and November25th in the lower longest $(15.8 \mathrm{~cm})$ in Table.1, Figure1. Fihure2.

The root collar diameter ranged from $(2.3$ to $1.8 \mathrm{~mm})$ and was recorded by October10th and October25th respectively. However October 10th sowing had significantly bigger root collar diameter compared to all sowing date. November10th ranked in the second place and was significantly bigger than the remainder of the sowing date. It recorded $(2.1 \mathrm{~mm})$. On the other hand November25th sowing was significantly bigger than the remainder of the sowing date recording $(2.0 \mathrm{~mm})$ and October25th recorded $(1.8 \mathrm{~mm})$ the last ranked. As shown in Table (2).

Number of leaves highest in October10th and October25th sowing were significantly than the remainder of the sowing date in 10th and 25th November recorded $(17,15.8)$ respectively as showing in Table.1.

The lengths of the seedlings varied significantly among the shade and under sun. The Seedlings under shade recorded the longest seedling length $(25.3 \mathrm{~cm})$ and number of leaves showed high significant under sun (18.2 leaves) as showing in Table 2.

The sowing in October 10th recorded significantly than the other remainder of the sowing date with the shoot length $(19.9 \mathrm{~cm})$, shoot fresh weight $(1.98 \mathrm{~g})$, shoot dry weight $(0.6 \mathrm{~g})$, root dry weight (1.2 $\mathrm{g})$ and biomass (1.8 $\mathrm{g})$ as showing in Table 3 .

The seedlings sowing under shade recorded significantly with the shoot length $(21.8 \mathrm{~cm})$ and shoot/root length ratio; the seedling sowing under sun showing high significantly with the root fresh weight $(1.6 \mathrm{~g})$ as showing in Table 4.

\section{DISCUSSION}

The result of the research confirm there are some significant differences for sowing date, the seed sowing in October give an excellent establishment of length, diameter and number of leaves for seedlings for each planted inside and outside the shade (under sun), and this is because the best times for Acacia senegal sowing in the nursery are in the beginning of October 10th. The comparing the seedling planting inside the nursery (shade) and the outside of the shade (under sun), it is find that they give the best length of planting when planted under shade, but there are no significant differences for the diameter in the both cases. There is a hardening and rapid establishment of seedlings that were planted outside the shade, and this appears by increasing the number of leaves for the seedlings, and these are advantages of plantation establishment for their dependence on photosynthesis.

\section{CONCLUSIONS AND RECOMMENDATIONS}

It is very important to know the appropriate condition for planting in the nursery to facilitate the difference operations and reduce the time and money.

- The beginning of October, the most appropriate date for planting with seedlings is hashab A. senegal seeds. 
- Preferable to plant in the nursery for the hashab A. senegal seedlings under shade in case of obtaining a better length and diameter for the seedlings.

- The hashab A. senegal seedlings are obtained rapid establishment and a adaptation of the seedlings can be planted under the sunlight.

- Cultivation of seedlings under the sunlight, rapid obtaining more roots and more number of leaves than under the shade.

\section{REFERENCES}

Elsiddig, E.A., (2003) Development of volume and height-diameter equations for Eucalyptus camaldulensis, Acacia nilotica and Acacia seyal in Sudan, Sudan Silva,9:1-13.

Fadl, K.M. and J. Gebauer,( 2004). Effect of different tapping tools and different tapping position on talh gum yield of Acacia seyal var, seyal in South Kordofan, Sudan, Proceedings of the Conference on International Agricultural Research for Development, Oct.5-7, Berlin, pp:1-6.

FAO. (1995). Non-wood forest products 7: Non-wood forest products for rural income and sustainable forestry. FAO, Rome, Italy.138 pg.

Gardens, Kew. (2016). Acacia Senegal (Gum Arabic). Board of Trustees of the Royal Botanic.

Mustafa, A. F. (1997). Regeneration of Acacia seyal forests on the dryland of the Sudan caly plain. Tropical Forestry Report No. 15. Department of Forest Ecology, Helsinki University Printing House.

Taha, M. E. (1999). The socioeconomic role of Acacia senegalin sustainable development of rural areas in the Gum Belt of the Sudan. PhD thesis. Technische Universität Dresden, Germany. 
Table.1 Mean parameters of Hashab (Acacia senegal) seedlings for different sowing date in nursery.

\begin{tabular}{|lccc|}
\hline Sowing date & Length $(\mathrm{cm})$ & $\begin{array}{c}\text { Collar diameter } \\
(\mathrm{mm})\end{array}$ & Number of leaves \\
\hline October10 & $24.6^{\mathrm{A}}$ & $2.3^{\mathrm{A}}$ & $17.0^{\mathrm{A}}$ \\
October25 & $18.6^{\mathrm{B}}$ & $1.8^{\mathrm{D}}$ & $15.8^{\mathrm{A}}$ \\
November10 & $15.8^{\mathrm{C}}$ & $2.1^{\mathrm{B}}$ & $12.7^{\mathrm{B}}$ \\
& & & \\
November $25^{\text {th }}$ & $15.8^{\mathrm{C}}$ & $2.0^{\mathrm{C}}$ & $13.9^{\mathrm{B}}$ \\
\hline
\end{tabular}

Means in the same row followed by the same letter do not differ (P > 0.05, LSD)

Table 2. Mean parameters of Hashab (Acacia senegal) seedlings sowing in the shade and sunlight.

\begin{tabular}{|cccc|}
\hline Shade & Length $(\mathrm{cm})$ & $\begin{array}{c}\text { Collar diameter } \\
(\mathrm{mm})\end{array}$ & Number of leaves \\
\hline Shade & $25.3^{\mathrm{A}}$ & $2.1^{\mathrm{A}}$ & $11.5^{\mathrm{B}}$ \\
Under sun & $12.2^{\mathrm{B}}$ & $2^{\mathrm{A}}$ & $18.2^{\mathrm{A}}$ \\
\hline
\end{tabular}

Means in the same row followed by the same letter do not differ $(\mathrm{P}>0.05$, Duncan)

Table.3 Mean parameters of Hashab (Acacia senegal) seedlings for different sowing date in nursery.

\begin{tabular}{|c|c|c|c|c|c|c|c|c|c|c|}
\hline & $\begin{array}{l}\text { Shoot } \\
\text { length }\end{array}$ & $\begin{array}{c}\text { Root } \\
\text { length }\end{array}$ & $\begin{array}{c}\text { Sh /rot } \\
\text { length } \\
\text { raio }\end{array}$ & $\begin{array}{l}\text { Shoot } \\
\text { fresh } \\
\text { weight } \\
\text { (g) }\end{array}$ & $\begin{array}{l}\text { Root } \\
\text { fresh } \\
\text { weight } \\
\text { (g) }\end{array}$ & $\begin{array}{l}\text { Sh/rot } \\
\text { fresh } \\
\text { raio }\end{array}$ & $\begin{array}{c}\text { Shoot dry } \\
\text { weight } \\
\text { (g) }\end{array}$ & $\begin{array}{l}\text { Root dry } \\
\text { weight } \\
\text { (g) }\end{array}$ & $\begin{array}{l}\text { Sh/rot } \\
\text { dry raio }\end{array}$ & $\begin{array}{c}\text { Biomass } \\
\text { (g) }\end{array}$ \\
\hline October $10^{\text {th }}$ & $19.9^{A}$ & $19.8^{\mathrm{A}}$ & $1^{\mathrm{A}}$ & $1.6^{\mathrm{A}}$ & $1.98^{\mathrm{A}}$ & $0.9^{A B}$ & $0.6^{\mathrm{A}}$ & $1.2^{\mathrm{A}}$ & $0.6^{\mathrm{B}}$ & $1.8^{\mathrm{A}}$ \\
\hline October $25^{\text {th }}$ & $15.9^{B C}$ & $21.2^{A}$ & $0.9^{A}$ & $0.95^{\mathrm{BC}}$ & $1.6^{\mathrm{AB}}$ & $0.6^{B}$ & $0.4^{B C}$ & $0.9^{A B}$ & $0.5^{B}$ & $1.3^{\mathrm{AB}}$ \\
\hline November $10^{\text {th }}$ & $19.3^{\mathrm{AB}}$ & $22^{\mathrm{A}}$ & $0.9^{A}$ & $1.2^{\mathrm{B}}$ & $1.1^{\mathrm{B}}$ & $1.3^{\mathrm{A}}$ & $0.5^{A B}$ & $0.6^{\mathrm{B}}$ & $1.05^{\mathrm{A}}$ & $1.1^{\mathrm{B}}$ \\
\hline November $25^{\text {th }}$ & $14.5^{C}$ & $19.8^{\mathrm{A}}$ & $0.8^{\mathrm{A}}$ & $0.8^{C}$ & $1.2^{\mathrm{B}}$ & $0.8^{B}$ & $0.3^{c}$ & $0.6^{\mathrm{B}}$ & $0.6^{\mathrm{B}}$ & $0.97^{B}$ \\
\hline
\end{tabular}

Means in the same row followed by the same letter do not differ (P > 0.05, Duncan) 
Table 2. Mean parameters of Hashab (Acacia senegal) seedlings sowing in the shade and sunlight.

\begin{tabular}{|ccccccccccc|}
\hline $\begin{array}{c}\text { Shoot } \\
\text { length }\end{array}$ & $\begin{array}{c}\text { Root } \\
\text { length }\end{array}$ & $\begin{array}{c}\text { Sh/root } \\
\text { length } \\
\text { raio }\end{array}$ & $\begin{array}{c}\text { Shoot } \\
\text { fresh } \\
\text { weight (g) }\end{array}$ & $\begin{array}{c}\text { Root } \\
\text { fresh } \\
\text { weight (g) }\end{array}$ & $\begin{array}{c}\text { Sh/rot } \\
\text { fresh raio }\end{array}$ & $\begin{array}{c}\text { Shoot dry } \\
\text { weight (g) }\end{array}$ & $\begin{array}{c}\text { Root dry } \\
\text { weight (g) }\end{array}$ & $\begin{array}{c}\text { Sh/rot } \\
\text { dry raio }\end{array}$ & $\begin{array}{c}\text { Biomass } \\
\text { (g) }\end{array}$ \\
Shade & $21.8^{\mathrm{A}}$ & $22.1^{\mathrm{A}}$ & $1^{\mathrm{A}}$ & $1^{\mathrm{A}}$ & $1.3^{\mathrm{B}}$ & $1^{\mathrm{A}}$ & $0.4^{\mathrm{A}}$ & $0.8^{\mathrm{A}}$ & $0.7^{\mathrm{A}}$ & $1.2^{\mathrm{A}}$ \\
Under sun & $13.1^{\mathrm{B}}$ & $19.3^{\mathrm{A}}$ & $0.7^{\mathrm{B}}$ & $1.2^{\mathrm{A}}$ & $1.6^{\mathrm{A}}$ & $0.9^{\mathrm{A}}$ & $0.4^{\mathrm{A}}$ & $0.9^{\mathrm{A}}$ & $0.6^{\mathrm{A}}$ & $1.4^{\mathrm{A}}$ \\
\end{tabular}

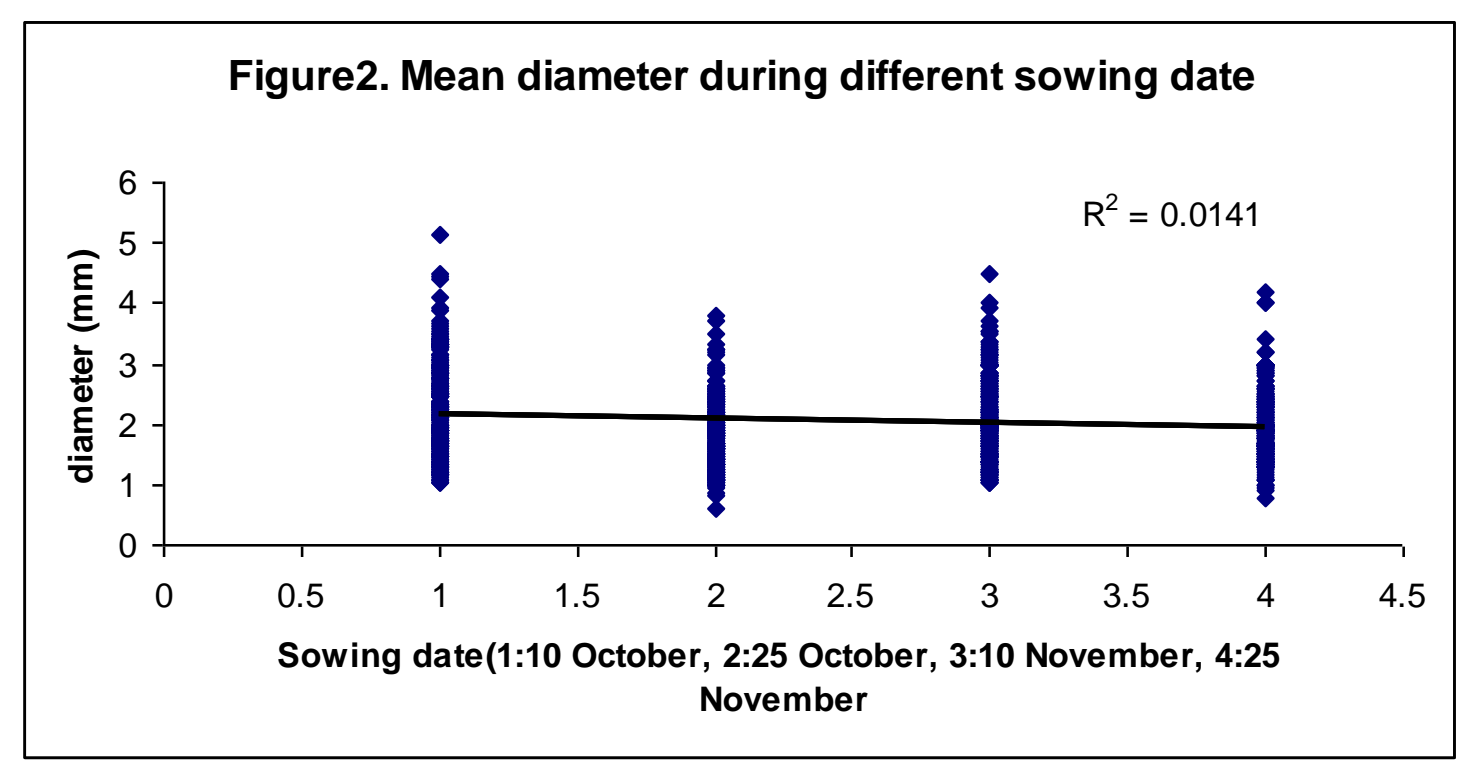

Figure2. Mean number of leaves during diferent sowing date

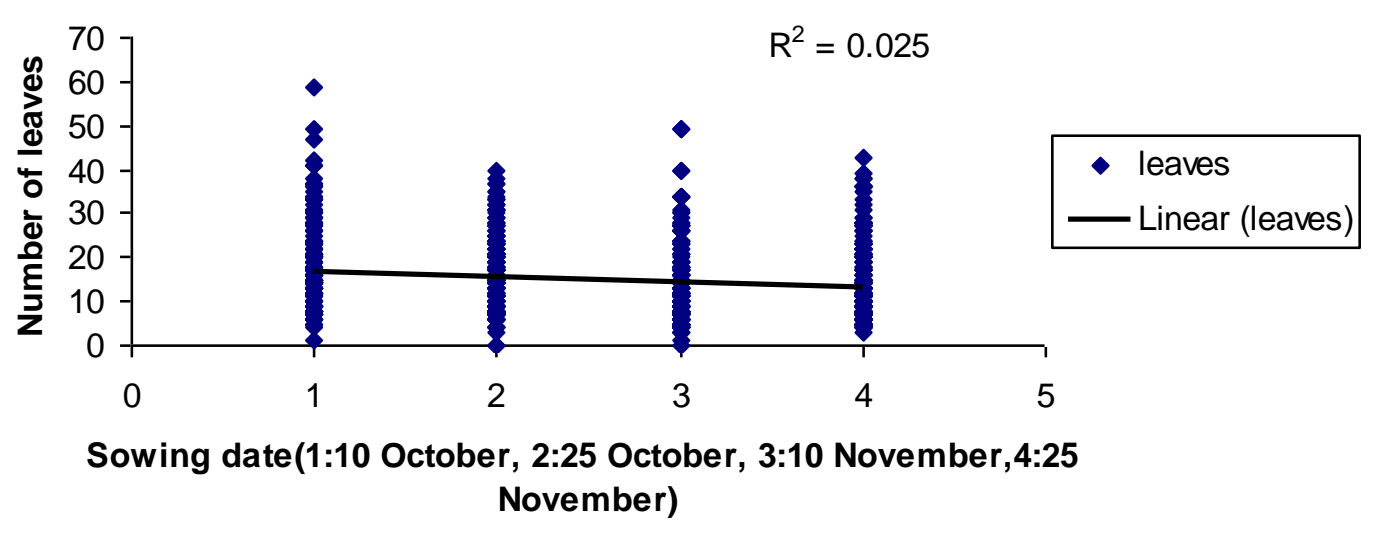

